\title{
Political Speech of Charitable Organizations Under the Internal Revenue Code
}

Throughout this nation's history the law has, as a matter of policy, given special consideration to charitable organizations and to their financial supporters. ${ }^{1}$ Section 170 (c)(2) of the Internal Revenue Code provides that donations to "qualified" organizations may be deducted" from the donor's gross income ${ }^{3}$ in computing income tax. Although contributions to an organization not formally qualified under section $501(c)(3)^{4}$ may be deducted under some circumstances, ${ }^{5} 501(\mathrm{c})(3)$ qual.

1 State and federal statutes provide charitable institutions and funds tax immunity. An institution may be granted exemption from both propery taxes and income taxes. Gifts to a charitable organization may lower the income tax or estate tax that would otherwise be demanded of the donor. As to the federal tax provisions, see INr. REv. CoDE of 1954 [hereinafter referred to as the Code]: section 170 (income tax of donor), section 501 (exemption of charity and other groups from income tax), section 2055 (estate tax), and section 2522 (gift tax). State statutes vary greatly. See generally 4 G. BOGERT, THE LAw OF Trusts and Trustees $\$ \$ 361-90$ (2d ed. 1964); 4 A. Scotr, Trusts $\$ \$ 370.4,373-374.6$ (3d ed. 1967). Charitable trusts have been extended a number of privileges not afforded other trusts. Among these are the enforcement of trusts with indefinite beneficiaries, exemption from the rule against perpetuities, and maintenance of the trust, through the cy pres doctrine, after its original purpose is no longer relevant. See Rrstatement (SECOND) of Trusts $\S \S 348-403$ (1959).

2 Section $170(c)(2)$ of the Code outlines restrictions on deductibility of personal contributions to approved organizations:

(c) Charitable Contribution Defined.-For purposes of this section, the term "charitable contribution" means a contribution or gift to or for the use of ...

(2) A corporation, trust, or community chest, fund, or foundation-

(A) created or organized in the United States or in any possession thereof, or under the law of the United States ....;

(B) organized and operated exclusively for religious, charitable, scientific, literary, or educational purposes or for the prevention of cruelty to children or animals;

(C) no part of the net earnings of which inures to the benefit of any private shareholder or individual; and

(D) no substantial part of the activities of which is carrying on propaganda, or other-

wise attempting, to influence legislation, and which does not participate in, or intervene in (including the publishing or distributing of statements), any political campaign on behalf of any candidate for public office.

Sections 2055 and 2522 of the Code deal respectively with deductibility of donations from estate and gift taxes. Both involve essentially the same restrictions on the nature of the recipient organizations as section $170(\mathrm{c})(2)(\mathrm{D})$. These restrictions correlate to the qualifications for section 501(c)(3) status. See note 4 infra.

3 Section 170(b) provides limitations on the amount an individual donor may deduct from his income in any given year for charitable donations. See note 98 infra.

4 Section 501(c)(3) of the Code sets the following criteria for eligibility:

Corporations, and any community chest, fund, or foundation, organized and operated exclusively for religious, charitable, scientific, testing for public safety, literary, or educational purposes, or for the prevention of cruelty to children or animals, no part of the net earnings of which inures to the benefit of any private shareholder or individual, no substantial part of the activities of which is carrying on propaganda, or 
ification allows the donor to be certain of the deductibility of his contribution. Most section $170(\mathrm{c})(2)$ contributions, therefore, are made to section 501 (c)(3) groups. ${ }^{6}$

To acquire and maintain status as a $501(\mathrm{c})(3)$ organization, ${ }^{7}$ a group must be "charitable,"8 and must not be substantially involved in political activity, including distribution of "propaganda," attempts to influence legislation, or participation in political campaigns. The "not substantially involved in political activity" criterion for 501(c)(3) status is not present in nontax definitions of a charity. ${ }^{\circ}$

otherwise attempting, to influence legislation, and which does not participate in, or intervene in (including the publishing or distributing of statements), any political campaign on behalf of any candidate for public office.

5 Section 170 (c)(2) does not require prior certification of the group to which the donation is made.

6 This explains why revocation of section $501(c)(3)$ status is thought to immediately result in a decline in donations. See note 22 infra.

7 Section 501 of the Code provides for the following categories of exempt organizations: charitable organizations (section 501(c)(3)), civic leagues and other social welfare groups (section $501(c)(4)$ ), labor, agricultural, or horticultural organizations (section 501(c)(5)), business associations (section 501(c)(6)), recreational clubs (section 501(c)(7)), and fraternal organizations (section 501(c)(8)). Only section 501(c)(3) groups may guarantee their donors the opportunity to deduct their contributions from their gross income. While virtually any group qualifying under section 501(c)(3) would also qualify under section 501(c)(4) as a social welfare group and thus would avoid taxation on income received, their donors would not be assured a section 170 (c)(2) deduction.

826 C.F.R. 1.501(c)(3)-1(d)(2) (1973) provides:

The term "charitable" is used in section 501(c)(3) in its generally accepted legal sense and is, therefore, not to be construed as limited by the separate enumeration in section 501(c)(3) of other tax-exempt purposes which may fall within the broad outlines of "charity" as developed by judicial decisions. Such term includes: Relief of the poor and distressed or of the underprivileged; advancement of religion, advancement of education or science; erection or maintenance of public buildings, monuments, or works; lessening of the burdens of Government; and promotion of social welfare by organizations designed to accomplish any of the above purposes, or (i) to lessen neighborhood tensions; (ii) to eliminate prejudice and discrimination; (iii) to defend human and civil rights secured by law; or (iv) to combat community deterioration and juvenile delinquency.

Frequently the Scott and Bogert treatises on trusts, supra note 1, are cited by the Treasury Department in analyzing whether a particular organization is "charitable" as that term is used in the Code. See, e.g., Rev. Rul. 72-209, 1972-1 Cum. Burr. 148. The Supreme Court has defined "charitable" as being anything that "tends to promote the well-doing and well-being of social man." Ould v. Washington Hosp. for Foundlings, 95 U.S. 303, 311 (1877). Whenever reference is made to one of the sanctioned purposes under section $501(c)(8)$ as "charitable," this should be understood as merely abbreviating the full list of approved purposes.

9 See cases cited note 71 infra. Restatement (SeCond) of Trusts § 374, Comment $j$ (1959) provides: "A trust may be charitable although the accomplishment of the purpose for which the trust is created involves a change in the existing law .... The mere fact ... that the purpose is to bring about a change in the law, whether indirectly through the education of the electors so as to bring about a public sentiment in favor of the change, or through proper influences brought to bear upon the legislators, does not prevent the purpose from being legal and charitable." This rule is accepted in virtually every American jurisdiction. See Scorr, supra note 1. The English common law rule is contrary. In re 
Although the requirement of "not substantially involved" is obviously subject to great discretion in application, the nature of "political activity" is relatively well understood. The courts have not entered into detailed discussions of the nature of "political activity," but in general every contact with public issues has been viewed as political, regardless of the position taken by the organization. ${ }^{10}$ Organizations have been deprived of their exempt status for lobbying for legislation, ${ }^{11}$ endorsing political candidates, ${ }^{12}$ publishing statements critical of government policy, ${ }^{13}$ recommending changes in existing law, ${ }^{14}$ and for endorsing such general positions as the desirability of pacifism ${ }^{15}$ or the World Court. ${ }^{16}$ No decision revoking 501 (c)(3) status for political activity has investigated either the effect that the restriction may have on speech, ${ }^{17}$ or whether the political activities engaged in were designed to further some appropriately charitable objective.

Hood, [1931] $1 \mathrm{Ch}$. 240; Inland Revenue Comm'rs v. Temperance Council of Christian Churches, 136 L.T.R. 27 (K.B. 1926); Habershon v. Vardon, 4 De G. \& Sm. 467, 64 Eng. Rep. 916 (Ch. 1851). In the United States, the only remaining limitation on the political activities of groups which otherwise qualify as "charitable" is that of the Code. See Clark, The Limitation on Political Activities: $A$ Discordant Note in the Law of Charities, 46 VA. L. REv. 439, 440-44 (1960).

10 See, e.g., notes 11-16 infra.

11 See, e.g., notes 12-16 infra, and Slee v. Commissioner, 42 F.2d 184 (2d Cir. 1930), a leading pre-Code decision denying a deduction because of the American Birth Control League's lobbying efforts to change laws limiting sales of contraceptives.

12 Watson v. Commissioner, 27 B.T.A. 463 (1932) (participation in political campaign held ground for denying deduction of contribution to group).

13 The Sierra Club is perhaps the best-known example. See letter from District Director of the Internal Revenue Service to Sierra Club, December 16, 1966, in 7 CCH 1967 STAND. FED. TAX REP. If 6376 at $71,383,71,398$.

14 Christian Echoes National Ministry, Inc. v. United States, 470 F.2d 849 (10th Cir. 1972) (religious group's support for constitutional amendment to permit prayer in public schools and a number of other political positions held substantial and sufficient ground for revocation of group's exemption).

15 The Fellowship of Reconciliation's advocacy of pacifism was grounds for revocation of exemption. Letter from Director, Tax Rulings Division, Internal Revenue Service, to the Fellowship of Reconciliation, Nyack, New York, January 10, 1963, in P-H FED. TAXES If 54,825. This IRS action was the subject of Note, The Revenue Code and a Charity's Politics, 73 Yale L.J. 661 (1964). See also Leubuscher v. Commissioner, 54 F.2d 998 (2d Cir. 1932) (denial of deduction for contribution to group advocating the "single tax" principle of Henry George).

16 Forstall v. Commissioner, 29 B.T.A. 428 (1933) (advocacy of entrance of the United States into League of Nations); cf. League of Women Voters of United States v. United States, 180 F. Supp. 379 (Ct. Cl. 1960) (advocacy of many political positions, including support of the World Court).

17 In two decisions first amendment challenges were raised but dismissed without discussion. "Americans United" Inc. v. Walters, 477 F.2d 1169 (D.C. Cir.), cert. granted, 412 U.S. 927 (1973); Winters v. Commissioner, 468 F.2d 778 (2d Cir. 1972). The effect of the political activities restriction on the free exercise of religion was discussed in Christian Echoes National Ministry, Inc. v. United States, 470 F.2d 849 (10th Cir. 1972). 
This comment discusses first amendment issues arising out of the political action restriction of $501(c)(3)$ and evaluates the possible justifications for this restriction as part of the Code's regulation of charitable organizations.

\section{The Effect of Segtion 501(c)(3) on Speech}

\section{A. Group Speech and the First Amendment}

Section $501(c)(3)$ 's restriction on political activity is addressed primarily to groups. There is no reason to believe, however, that the first amendment's protection is any less applicable to groups than to individuals. ${ }^{18}$ The purpose of the first amendment is to protect open discussion of issues. Thus whether the speaker is an individual or a group seems irrelevant. Indeed, group speech may be more important, because in some situations group action and resources are more effective. ${ }^{19}$ In interpreting the first amendment, the Supreme Court has not indicated that a group is subject to greater regulation than an individual, ${ }^{20}$ and has, in fact, routinely extended first amendment protection to group activities. ${ }^{21}$

B. Government Benefits and Restrictions Indirectly Affecting Speech: Modes of Constitutional Analysis

As noted above, "qualification" of an organization under 501(c)(3), which enables a donor to ensure his ability to deduct his donations,

18 It is also possible to argue that in the case of speech the organization has no life apart from its members. Although the group exercises the direct control over financing of speech, the final expression coming from the group cannot meaningfully be separated from the individuals who determined what that expression should be and indirectly provided the necessary funds. In this sense, the individuals might be thought to bring to the group first amendment protection sufficient to enable it to challenge section 501(c)(3)'s effect on speech.

19 "Effective advocacy of both public and private points of view, particularly controversial ones, is undeniably enhanced by group association." NAACP v. Alabama ex rel. Patterson, 857 U.S. 449, 460 (1958).

20 In NAACP v. Alabama ex rel. Patterson, 357 U.S. 449 (1958), the Court avoided specifically settling the question by finding that the organization may assert the associational rights of its members; five years later the Court held that the NAACP had the right to litigate (finding such litigation involved frst amendment activity) without referring to the rights of individual members. NAACP v. Button, 371 U.S. 415 (1963). Some lower courts have explicitly held that groups are entitled to full first amendment protection. See, e.g., Hanover Township Fed'n of Teachers Local 1954 (AFL-CIO) v. Hanover Community School Corp., 457 F.2d 456 (7th Cir. 1972).

21 See, e.g., Time, Inc. v. Hill, 385 U.S. 374 (1967); New York Times Co. v. Sullivan, 376 U.S. 254 (1964); Kingsley Int'l Pictures Corp. v. Regents of the University of the State of New York, 360 U.S. 684 (1959); Joseph Burstyn, Inc. v. Wilson, 343 U.S. 495 (1952); Grosjean v. American Press Co., 297 U.S. 283 (1936). 
frequently is vital to the organization's continued operation. ${ }^{22}$ Thus, in order to survive, the organization must diligently avoid political speech to meet the requirement that it refrain from substantial political activity. Ten years ago, the effect of the 501 (c)(3) restriction would probably have been viewed as an "unconstitutional condition."23 Under this analysis, the government is generally forbidden from requiring a recipient to choose between a valuable government benefit and a constitutionally protected right. ${ }^{24}$ The doctrine, however, may be of lim-

22 "Because of the 'tax breaks' attendant to contributions to corporations qualifying under section 170 (c) of the Code, qualification thereunder is a precious possession and revocation ... is a damaging-sometimes fatal-injury to the financial status of any 'charitable' organization. Potential contributors with a minimum of business acumen are careful to get the most for their contributed dollar, and one certain way not to do so is to contribute to non-section 170 corporations." "Americans United" Inc. v. Walters, 477 F.2d 1169, 1177 (D.C. Cir.), cert. granted, 412 U.S. 927 (1973). For example, following the Sierra Club's notice of review of its exempt status, supra note 13, the Club reportedly suffered losses in contributions of $\$ 5,000$ a week. Borod, Lobbying for the Public InterestFederal Tax Policy and Administration, 42 N.Y.U.L. REv. 1087, 1089 n.5 (1967). The Fourth Circuit has recently stated that even temporary loss of exempt status is an irreparable injury. Bob Jones University v. Connally, 472, F.2d 903 (4th Cir.), cert. granted 414 U.S. 817 (1973).

23 See Note, Unconstitutional Conditions, 73 HARv. L. Rev. 1595 (1960).

24 This doctrine developed in response to the parallel development of right-privilege distinctions, under which a government subsidy classified as a "privilege" could be distributed in virtually any way the government chose with virtually no conditions on its receipt subject to challenge, while the distribution of subsidies to which the individual had a "right" was carefully regulated. There are many decisions rejecting this distinction. In the past term the Court has repeatedly held that right-privilege distinctions are no longer meaningful. Perry v. Sindermann, 408 U.S. 593 (1972); Morrissey v. Brewer, 408 U.S. 471 (1972); Healy v. James, 408 U.S. 169 (1972). Other decisions have also freely imposed constitutional requirements on the distribution of government benefits. Graham v. Richardson, 403 U.S. 365 (1971) (state welfare benefits for aliens); Goldberg v. Kelly, 397 U.S. 254 (1970) (state welfare benefits); Sherbert v. Verner, 374 U.S. 398 (1963) (state unemployment benefits); Torcaso v. Watkins, 367 U.S. 488 (1961) (public employment).

In one of the earliest discussions of the unconstitutional conditions doctrine, Justice Sutherland took the view that unconstitutional conditions were those whose purpose was to regulate that which the state might not directly control:

It would be a palpable incongruity to strike down an act of state legislation which, by words of express divestment, seeks to strip the citizen of rights guaranteed by the federal Constitution, but to uphold an act by which the same result is accomplished under a guise of surrender of a right in exchange for a valuable privilege which the state threatens otherwise to withhold. It is not necessary to challenge the proposition that, as a general rule, the state, having power to deny a privilege altogether, may grant it upon such conditions as it sees fit to impose. But the power of the state in that respect is not unlimited; and one of the limitations is that it may not impose conditions which require the relinquishment of constitutional rights.

Frost \& Frost Trucking Co. v. Railroad Comm., 271 U.S. 583, 593-94 (1926). The unconstitutional condition cases may be viewed as implicitly concerned with the motives of the state in placing conditions on benefits that usually were totally unrelated to the basic purpose of the benefit. See, e.g., Lamont v. Postmaster General, 381 U.S. 301 (1965) (conditions on use of postage privileges); Hannegin v. Esquire, Inc., 327 U.S. 146 (1946) (dicta) (second class postage as form of subsidy). See also Danskin v. San Diego Unified School 
ited scope. The typical unconstitutional condition case invalidated use of an apparently arbitrary requirement against a disfavored minority. ${ }^{25}$ When the condition is not an invidious discrimination and is shown to be part of a rational government scheme, however, the Court has on occasion approved demands by the government that an individual give up a constitutionally protected right in return for a government benefit. For example, government employment may be predicated on adherence to the Hatch Act's ${ }^{26}$ twice upheld ${ }^{27}$ condition that a government employee not engage in certain partisan political activities.

Nothing could be more clearly within the purview of the first amendment than the expression of opinion on partisan political issues-indeed, such expression has been said to be at the heart of the first amendment. ${ }^{28}$ In upholding the Hatch Act's restrictions, the Court seems to be distinguishing between narrowly construed restraints that the government imposes in order to make efficient use of its work force and restraints that are irrelevant to employment. ${ }^{28}$ Thus the Act was upheld because its purposes were to eliminate political favoritism in employment and prevent corruption in hiring and firing of employees, ${ }^{30}$ while its restraints were only partial and limited to its purposes. ${ }^{31}$ This

District, 28 Cal. 2d 536, 171 P.2d 885 (1946); Housing Authority of City of Los Angeles v. Cordova, 130 Cal. App. 2d 883, 279 P.2d 215 (App. Dep't Super. Ct. 1955), cert. denied, 350 U.S. 969 (1956); Chicago Housing Authority v. Blackman, 4 IIl. 2d 319, I22 N.E.2d 522 (1954); Lawson v. Housing Authority of City of Milwaukee, 270 Wis. 269, 70 N.W.2d 605 (1955), cert. denied, 350 U.S. 882 (1955).

25 For example, in Danskin v. San Diego Unified School District, 28 Cal. 2d 536, 171 P.2d 885 (1946), Judge Traynor found that a school district had decided to permit the use of school facilities only by certain groups, arbitrarily excluding those with whom it disagreed (in that case, a local chapter of the ACLU). Similariy, in the Blackman, Lawson and Cordova cases, the state courts found loyalty oaths as a condition of entrance into federally subsidized housing were improper because unrelated to the purposes of the subsidy.

26 The specific prohibitions on political activity are enumerated at 5 U.S.C. $\$ \S 7328-24$ (1970).

27 United States Givil Service Comm'n v. National Association of Letter Carriers, AFLCIO, 413 U.S. 548 (1973); United Public Workers v. Mitchell, 330 U.S. 75 (1947).

28 Mills v. Alabama, 384 U.S. 214, 218-19 (1966); Mr. Justice Brennan, writing in New York Times Co. v. Sullivan, 376 U.S. 254, 270 (1964), commented:

[W] consider this case against the background of a profound national commitment to the principle that debate on public issues should be uninhibited, robust, and wideopen, and that it may well include vehement, caustic, and sometimes unpleasantly sharp attacks on government and public officials.

20 The Court has frequently stated that employment decisions "may not be predicated on [the] exercise of First and Fourteenth Amendment rights." Perry v. Sindermann, 408 U.S. 593, 598 (1972); see Keyishian v. Board of Regents, 385 U.S. 589 (1967); Shelton v. Tucker, 364 U.S. 479 (1960). This is clearly too broad a statement, as the Hatch Act cases demonstrate.

30 In part, the Supreme Court in Letter Carriers deferred to the legislative and executive judgment that the Act's prohibitions were necessary and effective. 413 U.S. at 564-67.

31 Id. 
balancing of the government's stated interests against the restraint on speech caused by the condition placed on receipt of a government benefit seems to be closely related to the balancing the Court employs to evaluate direct prohibitions of speech. ${ }^{\mathbf{3 2}}$

Perhaps because few unconstitutional condition cases involved plausible assertions of governmental interest in the regulation, the Court's discussions of the unconstitutional conditions doctrine never related that doctrine to the traditional first amendment "balancing of interests" test. Thus it is difficult to determine whether one test is a corollary of the other, or whether the Court intended to create a separate test for the indirect conditioning of general constitutional rights. It is also possible that the unconstitutional conditions doctrine originally imposed a separate standard of review which has since merged with the doctrine of balancing of interests.

Because of the confusing nature of the unconstitutional conditions doctrine, it would appear to be most useful to analyze the restrictions in 501 (c)(3) in terms of the Court's conventional approach to restrictions on speech. Only one case has considered the question whether restrictions on tax benefits premised on the speech activities of the recipient must be evaluated under the Court's general first amendment balancing test.

\section{G. Speiser v. Randall: Denial of Tax Exemptions as a Penalty for Speech}

In Speiser $v$. Randall, ${ }^{33}$ the Court was asked to rule on the validity of a California statute that denied veterans' property tax exemptions to individuals who had engaged in criminal subversive speech. Although the case was ultimately decided on procedural due process grounds, it contains an important discussion of the scope of a state's power to withhold tax benefits from individuals because of their speech. The Court noted first that the denial of an exemption "to claimants who engage in certain forms of speech is in effect to penalize them for such speech." 34 Rejecting the right-privilege distinction advanced by California, the Court made it plain that such a denial "necessarily will have the effect of coercing the claimants to refrain from the proscribed speech."35 Presumably where the speech is entitled to constitutional protection, the coercion violates the claimant's constitutional rights.

Of course not all speech is subject to such protection, and the pur-

32 See text and notes at notes $66-68$ infra.

33357 U.S. 513 (1958).

34 Id. at 518 .

85 Id. at 519 . 
pose of the California restriction-penalization of criminal subversive speech-was assumed to be acceptable. The Court's objection to the statute ultimately was that it did not sufficiently distinguish between criminal and noncriminal speech so as to guarantee that only the unprotected speech would be affected. ${ }^{36}$

The Speiser dictum concerning the relationship between speech and denial of tax exemptions was discussed by the Court the following year in Cammarano v. United States. ${ }^{37}$ Several courts have recently stated that Cammarano forecloses finding that the 501(c)(3) restriction is an impermissible restraint on speech, ${ }^{38}$ but this reading of the case is subject to doubt. Cammarano, a beer distributor, had sought to deduct as an "ordinary and necessary" business expense ${ }^{30}$ a contribution to a local business association trust fund. The purpose of the fund was to finance opposition to an initiative measure that, if passed, would have had a detrimental effect on his business. ${ }^{40}$ Relying on Speiser v. Randall, Gammarano claimed that the refusal to grant a deduction for the contribution violated his first amendment rights. ${ }^{41}$ The Court recognized,

36 Denial of the tax privilege created by section 32, Revenue and Taxation Code of California, was permitted only when the recipient had been involved in criminal subversive speech. This limitation was a provision of the state constitution. CALrF. CoNST. art. XX \& 19. The provision was narrowly construed by the California Supreme Court, which required that all relevant constitutional standards be employed in determining whether the speech in any particular case was criminal and thus without first amendment protection. See First Unitarian Church v. County of Los Angeles, 48 Cal. 2d 419, 428, 311 P.2d 508,513 (1957). The Supreme Court assumed that this indirect restraint on criminal speech was permissible because direct restraints were sanctioned, 357 U.S. 513,519 , but held that the statute created impermissible risks of self-censorship by taxpayers fearing loss of tax privilege:

The vice of the present procedure is that, where particular speech falls close to the line separating the lawful and the unlawful, and the possibility of mistaken factfinding -inherent in all litigation-will create the danger that the legitimate utterance will be penalized. The man who knows that he must bring forth proof and persuade another of the lawfulness of his conduct necessarily must steer far wider of the unlawful zone than if the State must bear these burdens.

Id. at 526 .

37358 U.S. 498 (1959).

38 "Americans United" Inc. v. Walters, 477 F.2d 1169, 1182 (D.C. Cir.), cert. granted, 412 U.S. 927 (1973); Winters v. Commissioner, 468 F.2d 778, 781 (2d Cir. 1972).

38 Int. Rev. Code of 1939, ch. 1, § 23(a)(1) (A), 52 Stat. 460 (now INT. Rev. Code of 1954, \& 162).

40 Brief for Appellant at 6-7, Cammarano v. United States, 858 U.S. 498 (1959).

41 Earlier, in Textile Mills Securities Corp. v. Commissioner, 314 U.S. 326 (1941), the Court denied a business deduction for lobbying activities. Cammarano argued that although Textile Mills prohibited deductions for lobbying efforts directed at affecting pending legislation, it did not prohibit deductions for efforts to influence public opinion on initiative issues. Brief for Appellant, supra note 40 , at 38-51. Justice Harlan, writing for the Court, rejected this distinction and treated Textile Mills as controlling. 358 U.S. at 513. 
however, that "Speiser has no relevance" 42 to Cammarano's case. The discussion in Speiser dealt with the denial of a deduction because the claimant had engaged in a constitutionally protected activity. The result of such a scheme was said to restrain the exercise of that activity due to a fear of losing the deduction. Cammarano, on the other hand, was not denied a deduction because he had engaged in speech; rather, he was not permitted to deduct the cost of the activity itself. His speech was in no way restrained; he was "simply being required to pay for those activities entirely out of [his] own pockets, as everyone else engaging in similar activities is required to do ...."43 The Court in Cammarano noted that "nondiscriminatory denial of deductions from gross income of sums expended to promote or defeat legislation is plainly not 'aimed at the suppression of dangerous ideas.' . . . . Rather, it appears to us to express a determination by Congress that since purchased publicity can influence the fate of legislation which will affect, directly or indirectly, all in the community, everyone in the community should stand on the same footing as regards its purchase so far as the Treasury of the United States is concerned." 44

The relationship between Speiser and Cammarano is clarified by a careful definition of the natures of the deductions in question. The business deduction involved in Cammarano bears no resemblance to the Speiser deduction or the deduction permitted by $170(c)(2)$. Business deductions such as those in Cammarano are permitted for particular expenses, while the Speiser statute and 501(c)(3) use one activity as the ground for denying deductibility for funds expended on entirely separate actions.

Cammarano was penalized neither for his speech activity nor for having claimed an impermissible deduction. The denial of Cammarano's attempted deduction of his lobbying expenses had no effect on his other business deductions, that year or in the future. Although a taxpayer may be encouraged to spend money on political activity if he is reimbursed for it through a deduction, a general refusal to subsidize political speech does not alone raise a constitutional issue. That a taxpayer is involved in speech-related activities does not, in itself, create a right to be subsidized.45 If other, independently legitimate business deductions had been affected by Cammarano's speech activities, however, a first amendment problem, considered by Justice Douglas to be analogous to

42358 U.S. at 513.

$43 I d$.

44 Id.

45 Justice Douglas expressly denied that this argument is valid. Id. at 515 (Douglas, J., concurring). 
Speiser, would have arisen..$^{46}$ Cammarano thus recognized that although the deduction could be denied, a penalty could not be imposed for nonoffending activities. Even if the decision in Cammarano were applied to 501(c)(3), it would allow denial of a deduction only for that portion of the charity's funds actually used to finance political activity. ${ }_{0}^{47}$

It is apparent that Cammarano does not overrule or contradict the Speiser dictum that tax benefits may not be denied as a consequence of a claimant's exercise of his first amendment rights and does not foreclose inquiry concerning the restraint on speech that seems to be imposed on groups by section $501(c)(3)$.

\section{The Effect of the Application of Section 501(c)(3) Standards}

As noted above, 48 section 501 (c)(3) qualification explicitly requires a charitable organization to limit its political speech. It is clear that qualification is frequently a practical necessity for the survival of a charitable organization, ${ }^{49}$ and thus the 501 (c)(3) limitation effectively penalizes claimants who engage in such speech activity. As the Supreme Court noted in Speiser, ${ }^{50}$ this will have the effect of uniformly forcing charitable organizations to refrain from political speech, ${ }^{51}$ a result that presents at least a prima facie violation of the first amendment.

In addition, $50 \mathrm{I}(\mathrm{c})(3)$ appears in practice to be interpreted in ways that discriminate between types of political speech and, as a result, between different types of groups. One discrimination, relating to the definition of "political activity," is entirely court-created. Another discrimination, stemming from the "substantially involved" criterion, is inherent in the statute and potentially aggravated by court-created discrimination.

The first type of discrimination is created when courts declare clearly political activity to be outside the prohibitions of 501(c)(3). For example, three courts have carved out an exception to the general 501 (c)(3) rule by declaring that bar associations could retain their 501 (c)(3) status in spite of the associations' activities supporting and opposing proposed

$46 \mathrm{Id}$.

47 The distinction would be extremely difficult to administer when dealing with the deductibility of an individual's contribution-requiring a separate percentage deduction for each charity-and problematic even if applied only to the group's tax liabilities. See note 99 infra.

48 Text and notes at notes 2 \& 4 supra.

49 Sce text and note at note 22 supra.

50 357 U.S. 513, 518-19.

61 See, e.g., notes 11-16 supra. There are relatively few instances where a statute prohibiting speech has been found impermissibly restrictive even when narrowly construed. But see, e.g., Mills v. Alabama, 384 U.S. 214 (1966). The more frequent case has been where 
legislation..$^{52}$ In one of those cases, ${ }^{53}$ the Second Circuit justified the result by attempting to distinguish between the legislative activity of the New York Bar Association and that of other groups. The court said: "These activities [reporting to the legislature on various proposals] serve no selfish purpose of the legal profession-rather they constitute an expert's effort to improve the law in technical and noncontroversial areas. In our opinion these activities are scientific, educational and charitable."54

Although selflessness is clearly relevant to the basic charitable nature of an organization, ${ }^{55}$ motive and effect have generally been treated as irrelevant to the "no substantial political activities" criterion of $501(c)(3) .{ }^{56}$ No other decisions have explicitly adopted a test that allows a group's "charitable" motivation to exempt its political activities from the prohibition of $501(c)(3)$, but several have suggested that such a test would be appropriate in certain cases. ${ }^{57}$ The ultimate outcome of such a test, of course, is to make an organization's 501(c)(3) status solely dependent on its charitable nature (as defined in the first part of $\left.501(c)(3)^{58}\right)$ regardless of any political nature of its charitable activities. This may be the only constitutionally permissible test; ${ }^{59}$ in current usage, however, the "charitable motivation" exception to the general

the statute was nondiscriminatory, but left too great a power of discretion in the hands of those responsible for administering it. See, e.g., Cox v. Louisiana, 379 U.S. 536 (1965); Cantwell v. Connecticut, 310 U.S. 296 (1940); Hague v. Committee for Industrial Organization, 307 U.S. 496 (1939); Lovell v. Griffin, 303 U.S. 444 (1938). Some commentators have suggested that the enforcement of section $501(c)(3)$ has been so selective as to raise a problem of discrimination. See, e.g., Borod, supra note 22; Note, The Revenue Code and a Charity's Politics, 73 YALE L.J. 661 (1964). See also discussion in text and notes at notes 52-62 infra. There is no constitutional reason, however, why discrimination either on the face of the statute or in its application must be shown before a first amendment challenge can be raised.

62 St. Louis Union Trust Co. v. United States, 374 F.2d 427 (8th Cir. 1967) (St. Louis Bar Association); Dulles v. Johnson, 273 F.2d 362 (2d Cir. 1959), cert. denied, 364 U.S. 834 (1960) (New York City, County, and State Bar Associations); Rhode Island Hosp. Trust Co. v. United States, 159 F. Supp. 204 (D.C.R.I. 1958) (Rhode Island Bar Association).

53 Dulles v. Johnson, 273 F.2d 362 (2d Cir. 1959), cert. denied, 364 U.S. 834 (1960).

54 Id. at 367.

55 See notes 4, 7 \& 8 supra.

56 Kuper v. Commissioner, 332 F.2d 562, 563 (3d Cir.), cert. denied, 379 U.S. 920 (1964) rejects the view that reviewing courts should look to the motives behind the political activity in applying the 501 (c)(3) restriction. See also Krohn v. United States, 246 F. Supp. 341, 347 (D. Colo. 1965); League of Women Voters of the United States v. United States, 180 F. Supp. 379 (Ct. Cl. 1960).

57 See, e.g., Seasongood v. Commissioner, 227 F.2d 907 (6th Cir. 1955); cases cited note 56 supra.

58 See note 4 supra.

69 See discussion page $374-76$ infra. 
prohibition of substantial political activity is discriminatorily granted to only a few organizations.

A second form of discriminatory application occurs as a result of the "substantially involved" element of the political activity criterion. "Substantially involved" is generally interpreted as referring to the percentage of a group's resources that is devoted to political activity. ${ }^{\text {B0 }}$ The requirement thus discriminates against less well-funded groups because a lesser absolute amount of political activity will disqualify them. ${ }^{61}$ Even if an absolute standard is imposed, however, the criterion of "substantial involvement" inherently discriminates against controversial organizations.

This discrimination against controversial groups is easily demonstrated. Assume there are two groups qualifying as charitable under 501 (c)(3). One is dedicated to the preservation of $X$, the other is dedicated to the elimination of $X$ (both on charitable grounds). A bill is introduced in Congress providing for the elimination of $X$, and public opinion, the political parties, and governmental agencies all favor the bill. Assuming normal circumstances, the organization in favor of the preservation of $X$ will $^{-}$have to wage a much more extensive political campaign in order to achieve its charitable goal. It will thus face the choice of imperiling its 501(c)(3) status (and thus its existence) or abandoning its valid, but controversial, charitable objective. The organization for the elimination of $X$, on the other hand, will need to engage in only limited political activity (probably not substantial) in order to have its objective achieved. In this type of situation, the more controversial the organization, the less likely it is to achieve its goals without losing its 501 (c)(3) status, in other words, the greater the discrimination against it.

This discrimination against controversial organizations may be aggravated if, as suggested by Krohn $v$. United States, ${ }^{62}$ the trier of fact has broad discretion to determine how much political activity is "substantial." Within the bounds of its discretion, the trier of fact may grant a far more lenient standard to a favored group than to a disfavored (probably controversial) organization. Discrimination of this sort does not inhere in the requirements of 501 (c)(3), but it is produced with an ease far beyond that allowed by the Court in other instances of restraints on protected speech.

It appears, therefore, that the $501(\mathrm{c})(3)$ prohibition of "substantial

60 See cases cited note 56 supra.

61 It is possible that this discrimination has been reduced. See note 99 infra.

62246 F. Supp. 341 (D. Colo. 1965). 
involvement in political activities" is both a general restraint upon speech and a discriminatory restraint in practice, the latter due in part to the nature of the restriction and in part to abuses by the courts. Under the traditional test for deciding whether such a restraint may stand, it must be determined whether the justifications for the-restraint outweigh the injury it causes.

No clear constitutional doctrine governs the process by which a reviewing court balances interests in deciding whether restraint on speech is justified. ${ }^{63}$ The competing interests are not difficult to define: speech must be protected to preserve as robust and vital a discussion of public issues as possible, but the state must preserve and accomplish the other myriad social tasks assigned to it, in some instances by imposing limitations on speech. ${ }^{64}$

The problem is in determining how to balance these interests. The

63 The Supreme Court has utilized two methods of balancing the state's interest in its restrictions and the individual's interest in the right affected. Where the right is "fundamental," as speech has been held to be in, for example, Mills v. Alabama, 384 U.S. 214 (1966), and New York Times v. Sullivan, 376 U.S. 254 (1964), the state must show a "compelling state interest" in the purpose the restriction was intended to accomplish; where the individual interest is less than fundamental, normally the state need only show a rational relationship between the restriction and some plausible state interest. This two-tier approach is generally thought to date from Justice Stone's opinion in United States v. Carolene Products Co., 304 U.S. 144, 152 n.4 (1938). The approach has been criticized as being excessively mechanistic and conclusory. Comment, Fundamental Personal Rights: Another Approach to Equal Protection, 40 U. CHI. L. REv. 807, 831 (1973). Professor Gunther has argued that the test should be the extent to which the restriction can be shown to actually accomplish the purpose the state claims for it and that this "means-focused" analysis should be substituted for the two-tiered approach. The Supreme Court, 1971 Term -Foreword: In Search of Evolving Doctrine on a Changing Court: A Model for a Newer Equal Protection, 86 HaRv. L. Rev. 1, 20 (1972). In the first amendment area the Court has at times refused entirely to classify the weight of the right. See, e.g., United States Civil Service Comm'n v. National Ass'n of Letter Carriers, 413 U.S. 548 (1973).

64 Tax exemptions can be thought of as a form of government subsidy; the government permits certain groups to avoid taxation because of the government's interest in the services performed by those groups. Bittker, Accounting for Federal "Tax Subsidies" in the National Budget, 22 NAT'L TAx J. 244 (1969), and citations at $244-46$ thereof; Surrey \&: Hellmuth, The Tax Expenditure Budget-Response to Professor Bittker, id. at 528; Bittker, The Tax Expenditure Budget-A Reply to Professors Surrey o Hellmuth, id. at 538; Surrey, Tax Incentives as a Device for Implementing Government Policy: A Comparison with Direct Government Expenditures, 83 HARv. L. REv. 705 (1970); Surrey, Federal Income Tax Reform: The Varied Approaches Necessary to Replace Tax Expenditures with Direct Governmental Assistance, 84 FARv. L. REv. 352 (1970). The rationale for tax exemptions has been similarly explained by a number of courts. Christian Echoes National Ministry, Inc. v. United States, 470 F.2d 849, 853-54 (10th Cir. 1972); Duffy v. Birmingham, 190 F.2d 738, 740 (8th Cir. 1951); American Women Buyers Club, Inc. v. United States, 235 F. Supp. 668, 672 (S.D.N.Y. 1963), aff'd, 338 F.2d 526 (2d Cir. 1964).

The government's interest in the section 501(c)(3) political action restriction must then depend on the extent to which its exemptions for charities actually promote important interests, balanced by the extent to which this interest is harmed by extending tax benefits to groups involved in political speech. 
government has considerable flexibility in fashioning solutions to social problems, and its actions are normally not subject to strict judicial review. Rather, government action is usually afforded a presumption of validity, and the government need only demonstrate some rational purpose behind the statute for it to be upheld. ${ }^{B 5}$ This presumption is shifted, however, when the regulation affects rights that the Supreme Court has held to be "fundamental." 66 As has been shown, the 501(c)(3) criterion of "no substantial political activity" restricts the speech of organizations. Free speech is one of the few rights unquestionably viewed as "fundamental," and whatever the precise nature of the balance to be struck, it is clear that the government has the burden of showing that its interest in the $501(\mathrm{c})(3)$ political activity criterion outweighs the restraint on free speech that it creates.

\section{Justifications for the Code Prohibition: The Problem of Balancing Interests}

When a regulation is analyzed under the first amendment balancing test, the government must show some interest in the regulation that outweighs the harm inflicted; yet when the balancing is between two important interests there is no clear standard that defines which is the more important. The following analysis of possible justifications for the prohibition on political activity of charitable groups imposed by section $501(c)(3)$ suggests the points at which there is conflict between the interests of the government and those of the individual and discusses how the balancing should be done. This assessment is not meant to predict judicial response but merely to suggest possible responses.

A number of different rationales may be devised to justify the Code prohibition. These will be considered under three broad classes of policies: the policy of maintaining rigorous standards for qualification as a charitable organization, the policy of avoiding public support for political controversies, and the policy of maximizing tax revenues.

A. The Policy of Maintaining Rigorous Standards for Qualification as a Charitable Organization

The government has an interest in guaranteeing that only "charitable" organizations-those which provide valuable social benefits-

05 Thus, in Cammarano v. United States, 358 U.S. 498, 512-13 (1959), the Court found the tax deduction involved did not affect speech and accordingly did not subject the statute to strict scrutiny. See text and notes at notes 37-45 supra.

66 Among such rights are: voting, Dunn v. Blumstein, 405 U.S. 330 (1972); travel, Shapiro v. Thompson, 394 U.S. 618 (1969); privacy, Roe v. Wade, 410 U.S. 113 (1973); and, of course, speech, Mills v. Alabama, 384 U.S. 214 (1966); New York Times Co. v. Sullivan, 376 U.S. 254 (1964). 
receive the valuable government benefits intended to promote such private activities. Private groups that do not provide any public advantage are justifiably excluded. ${ }^{67}$ To enforce this interest, the government may set standards to distinguish among groups. It is questionable, however, whether the political activity criterion is a justifiable means of ensuring the charitable nature of an organization. If the efforts of a politically active charitable group are not designed to benefit any individual, but rather are broadly public and unselfish, that group does not appear to be any less charitable because of its decision to secure public ends through political means. ${ }^{68}$

When the political activities restriction was first codified in 1934, ${ }^{69}$ a charity might have had more difficulty explaining political conduct than it would today. The pre-New Deal government had far less involvement in those areas traditionally viewed as charitable than does the government today, and there was less need for a charity to interact with government. ${ }^{70}$ One interpretation of the restriction is that it was an accurate assessment of 1934 realities: government was concerned with politics and charities were concerned with social welfare, so that the restriction provided a convenient administrative technique for gauging charitable purpose. The "substantially" test would then be viewed as an outlet for the occasional group that did engage in some political activity, yet remained charitable. This explanation of why the Congress may have determined to amend the Code at it did, however, does not justify the present retention of those provisions.

67 See note 64 supra.

$68 \mathrm{It}$ is also possible to ask whether the present legal definition of what is charitable is sufficiently broad. That question, however, is beyond the scope of this comment.

69 Revenue Act of 1934 \& 23(0)(2), 48 Stat. 690 (1934).

70 One authority on American philanthropy has concluded that there were areas of social welfare that in 1930 "would have been deemed to lie wholly in the field of private "charity" " in which by 1950 government expenditures were nine times those of private donors. F. ANDrews, Philanthropic Grving 43 (1950). For a more contemporary discussion, see F. Dickinson, The Changing Position of Philanthropy in the American Economy (1970). The following table demonstrates the diminished role of private giving vis-a-vis governmental expenditures in selected areas.

Expenditures for Selected Programs, 1970 (in millions)

\begin{tabular}{|c|c|c|c|}
\hline & Federal & State \& Local & Private \\
\hline Public Assistance & 18,456 & 14,679 & 1,400 \\
\hline Health Services & 12,907 & 1,806 & 3,200 \\
\hline Housing Programs & 4,030 & 2,138 & 一 \\
\hline Hospitals & 1,802 & 7,863 & - \\
\hline Education & 7,289 & 52,718 & 3,100 \\
\hline Religion & - & - & 8,300 \\
\hline Civic \& Cultural Events & - & - & 1,200 \\
\hline Scientific Research & 14,708 & - & 920 \\
\hline Parks \& Recreation & 370 & 1,888 & - \\
\hline Natural Resources & 3,647 & 2,732 & \\
\hline
\end{tabular}

Source: Statistical Abstract of the United States 388, 415, 521 (1972). 
Abstention from political activity was not a requisite attribute of an American common law charity when the provisions were codified ${ }^{71}$ and there does not appear to be any reason to conclude that a group cannot be both charitable and involved in political activity. ${ }^{22}$ In Slee $v$. Commissioner, ${ }^{73}$ a leading case decided before the present Code provisions were drafted, Judge Learned Hand denied a deduction to the American Birth Control League but recognized that political activity was not in itself incompatible with charitable ends:

Nevertheless, there are many charitable, literary and scientific ventures that as an incident to their success require changes in the law .... All such activities are mediate to the primary purpose, and would not, we should think, unclass the promoters. The agitation is ancillary to the end in chief, which remains the exclusive purpose of the association.

This recognition of "charitable" political activities continued after the enactment of the provision of $501(c)(3)$, with some courts deciding

71 See, e.g., Collier v. Lindley, 203 Cal. 641, 266 P. 526 (1928) (trust to be used for promoting improvements in the nature and structure of government, promoting public ownership of utilities, and securing legislation to benefit the American Indian); Garrison v. Little, 75 Ill. App. 402 (1898) (trust to promote women's rights); Register of Wills v. Cook, 241 Md. 264, 216 A.2d 542 (1966) (trust to eliminate discrimination against women); Jackson v. Phillips, 96 Mass. (14 Allen) 539 (1867) (trust to distribute literature and hold lectures advocating the abolition of slavery); George v. Braddock, 45 N.J. Eq. 757, 18 A. 881 (Ct. Err. \& App. 1889) (trust to distribute the works of Henry George advocating the "single tax"); Taylor v. Hoag, 273 Pa. 194, 116 A. 826 (1922) (trust to promote improvements in the structure and method of government); Lewis's Estate, $152 \mathrm{~Pa}$. 477, $25 \mathrm{~A} .878$ (1893) (trust to promote the ending of discrimination against Negroes); Peth v. Spear, 63 Wash. 291, 115 P. 164 (1911) (trust to provide a place where socialism could be taught). See generally 4 A. ScoTr, TRUsTs $\$$ 373-374.6 (3d ed. 1967).

This is the position of virtually every American jurisdiction. See note 9 supra. The rationale for the differing English rule was explained by Lord Parker in Bowman v. Secular Society, [1917] A.C. 406, to be that a court has no means of judging whether a particular purpose will or will not be for the public benefit when that purpose involves political theory, and therefore cannot" say whether a gift to secure such a purpose is charitable. The American response is summarized in REstatement (SECOND) of Trusts \& 374 (1959), comment $l$ :

The courts do not take sides or attempt to decide which of two conflicting views of promoting the social interest of the community is the better adapted to the purpose, even though the views are opposed to each other. Thus, a trust to promote peace by disarmament, as well as a trust to promote peace by preparedness for war, is charitable.

72 Professor Scott concludes: "Many reforms can be accomplished only by a change in the law, and there seems to be no good reason why the mere fact that they can be accomplished only through legislation should prevent them from being valid charitable purposes." 4 A. Scort, Trusts \& 374.4 at 2912 (3d ed. 1967). There is nothing in the legislative history of the Code which suggests that any belief in a necessary incompatibility between charitable activities and political activities was the rationale for the Code provision. See 78 Conc. REc. 5861 (1934).

7342 F.2d 184, 185 (2d Cir. 1930). 
that certain groups were sufficiently unselfish to qualify ${ }^{74}$ despite the literal language of the Code, and other courts emphasizing the charitable and desirable work of groups which they then hold must lose their $501(c)(3)$ status for violation of the prohibition on political activity. ${ }^{75}$

The legislative history of the political activity restriction does not indicate that it was drafted as a codification of the common law definition of charity. ${ }^{76}$ There is a suggestion in the legislative history, however, that the restriction was designed not merely to police the actions of the organizations, but also to test the purity of the donor's intent. ${ }^{77}$ The implication is that a donor to an organization involved in political activities is necessarily motivated less by pure generosity than by some selfish purpose and that donors should be policed by controlling the organization. It is difficult, however, to show that a donor's motive is affected by the organization's political activity and to justify the injury done to the organization because of the donor's intent. Organizations presumably receive donations from a wide range of individuals, all of whose motives for the donation may differ, yet the organization may still use the funds for purely charitable purposes. In addition, even if donor intent was at one time a reason for the 501 (c)(3) restriction, it no longer need be. Courts now regularly review donor intent in tax cases by determining whether the gift was the result of a "detached and disinterested generosity" 78 or whether it was a concealed payment for benefits received..$^{79}$ The government may deny $170(\mathrm{c})(2)$ deductions to a

74 See text and notes at notes 58-59 supra.

75 Dahlinger v. Commissioner, 20 B.T.A. 176 (1930) (upholding the exempt status of the Pennsylvania League of Women Voters). Even when the statute has been applied literally against a League of Women Voters the court has emphasized that the League's activities were unselfish and entirely proper-yet excluded by the statute. See, e.g., Kuper v. Commissioner, 332 F.2d 562 (3d Cir.), cert. denied, 379 U.S. 920 (1964); League of Women Voters of the United States v. United States, 180 F. Supp. 379 (Ct. Cl. 1960).

76 There was, however, a suggestion that, were the restrictions on political activity to be adopted by the Senate, many groups no Senator wished to penalize would be excluded. The colloquy in the Senate debate indicates how uncertain the legislators appear to have been in adopting the prohibition. 78 CoNG. REc. 5861 (1934).

77 Senator Reed commented in debate:

There is no reason in the world why a contribution made to the National Economy League should be deductible as if it were a charitable contribution if it is "a selfish one made to advance the personal interests of the giver of the money. That is what the committee were trying to reach; but we found great difficulty in phrasing the amendment. I do not reproach the draftsmen. I think we gave them an impossible task; but this amendment goes much further than the committee intended to go.

Id.

78 The language is taken from Commissioner v. Duberstein, 363 U.S. 278, 285 (1960), which, although the case concerned a transfer claimed by the taxpayer to be a gift under section 102 of the Code, has also been used as a test concerning a section $170(c)(2)$ contribution. See, e.g., Dejong v. Commissioner, 309 F.2d 373 (9th Cir. 1962).

79 This was the finding in Winters v. Commissioner, 468 F.2d 778 (2d Cir. 1972), which 
donor without affecting the 501 (c)(3) status of the group to which the donation was made. It is therefore difficult to justify the 501 (c)(3) criterion by an interest in pure donative intent.

\section{B. The Policy of Avoiding Public Support for Political Controversies}

A second possible justification for restraining political speech by charitable organizations is the avoidance of public support for political controversies. This justification is based on the view that allowing donors to deduct their contributions-thus lowering their tax liabilities -amounts to government support of the organization's activity ${ }^{80}$ and that such support for political activities is inappropriate.

Avoidance of this support could be defended on the ground that it may permit the government to discriminate between points of view or even control the groups. In addition, as an abstract matter it seems reasonable to prefer that public debate over political issues be conducted without government influence, even when that influence is caused only by necessary imperfections in efforts to distribute public funds fairly to all points of view. ${ }^{81}$ Although it might be argued that these concerns are irrelevant and insubstantial, ${ }^{82}$ an alternative and more moderate response points out that the policy has been ignored too frequently to be defended as sufficiently compelling to justify a restraint on protected speech.

A group that has been granted 501(c)(3) status may still participate in political activities if it is so large that its political activity is "insubstantial"83 or if it is in agreement with government policy and thereby is able to achieve its political goals without substantial expenditures. Thus the restriction in 501(c)(3) arguably restricts only some groups and permits others to continue to attract tax deductible contributions while participating in political activity.

The undermining of the general policy against public support for political activity is further demonstrated by the recent trend of congressional grants of tax deductions for political expression. Although in the past there may have been strong support for the proposition that

disallowed a contribution to a private religious elementary school on the ground that it was not a gift but compensation for services rendered. See also Oppewal v. Commissioner, 468 F.2d 1000 (lst Cir. 1972).

80 See commentary cited note 64 supra.

81 It might be argued that a group necessarily must be more hesitant to attack an administration which is responsible for financing it than would be true were the group wholly independent of the government.

$82 \mathrm{It}$ is currently popular to argue that only by providing public funding of partisan campaigns can corruption be avoided. To the extent that this argument has merit, it would appear its proponents assume government financing would be nondiscriminatory and fair.

83 See discussion in text at note 60 supra. 
public debate is best conducted when subsidization is at a minimum, ${ }^{84}$ in recent practice the government has subsidized several forms of public debate. Since Cammarano, Congress has provided for deductions for lobbying by businessmen ${ }^{85}$ and for individual contributions to political parties (up to $\$ 50) .{ }^{86}$ In addition, the government, in particular the executive, now engages directly in public policy debate; for example, the Defense Department lobbies for allocations ${ }^{87}$ and uses government resources to influence public opinion. ${ }^{88} \mathrm{It}$ is difficult, therefore, to accept the argument that the government truly does remain apart from political controversies.

The inconsistencies in the policy of nonsubsidization become more glaring in light of the role of litigation by charitable organizations, not restricted by the Code, in achieving changes in public policy. Charitable groups such as the American Civil Liberties Union accomplish changes in law through the process of private litigation without losing their exempt status. The restriction of $501(\mathrm{c})(3)$ thus limits only one vehicle of social change, yet there appears to be no reason why issues that cannot be affected by private litigation are less deserving of consideration by charitable organizations or why government subsidies of litigation are any less offensive to the principle that government should avoid support of political action. Moreover, because certain issues cannot be litigated, the restriction on political speech only restricts participation in some public policy debates, but not all. ${ }^{89}$

84 Both Cammarano v. United States, 358 U.S. 498, 512 (1959), and Slee v. Commissioner, 42 F.2d 184, 185 (2d Cir. 1930), refer to this avoidance of public support for political controversies, but neither attempts to articulate why this policy is desirable or what evils it is designed to avoid.

85 INT. Rev. CODE OF 1954 \& 162(e).

86 INT. REv. CoDe OF 1954 § 218.

87 It is of course well known that executive agencies and departments frequently testify before legislative committees. In one sense, this can be viewed as a use of public resources to affect legislative decisions (particularly appropriations, although such appearances are not limited to appropriations hearings) and can be thought of as lobbying.

88 J. Fulbrigrt, The Pentagon Propaganda Machine (1971). Senator Fulbright details the use of public relations techniques by all branches of the armed services to improve their public image and gain support for their policies.

89 Restrictions on what issues can be litigated, such as the case or controversy requirement, U.S. ConsT., art. III, and the judicially imposed limitation on review of "political questions," Luther v. Borden, 48 U.S. 1 (1849), restrict litigation of certain types of but not all political issues. Litigation resulted in desegregation of "separate but equal" educational facilities, Brown v. Board of Educ., 347 U.S. 483 (1954); realignment of malapportioned state legislatures and federal congressional districts, Reynolds v. Sims, 377 U.S. 533 (1964); Baker v. Carr, 369 U.S. 186 (1962); invalidation of state abortion laws, Roe v. Wade, 410 U.S. 113 (1973); invalidation of state laws governing the sale and use of contraceptives, Griswold v. Connecticut, 381 U.S. 479 (1965); modification of state laws governing voter qualifications for state and federal elections, Dunn v. Blumstein, 405 U.S. 
In sum, even if it were true at the time of Learned Hand's pronouncement in Slee that the government remained apart from such controversies and that there was a clear policy of avoiding support for political activity, the same proposition is difficult to defend today. Given the dilution of the policy since Cammarano, and the questionable accuracy of the claim that the government is impartial in such matters, it is doubtful that this policy is so compelling as to justify a restriction on freedom of speech.

A second facet of this policy is more troublesome. It might be argued that tax exemptions for political activity have the effect of providing government support for political activity and that this support gives an unfair advantage in debate to large accumulations of private wealth. It appears that this concern was an important rationale for the 1969 Tax Reform Act, which amended the Code to restrict the political activities of foundations.90

Wealthy individuals doubtless have the ability to use their wealth to attempt to influence public policy. Tax exemptions for this activity can be viewed as aggravating this inequality. Wealthy individuals can afford to give more, thus permitting them to enjoy a greater absolute subsidy and, as a consequence of our system of graduated rates, to receive a greater subsidy per dollar contributed.91 This argument seems to have special force when applied to foundations with large capital reserves, for a number of foundations have resources far beyond those that any group of private individuals can match. ${ }^{92}$

330 (1972); Carrington v. Rash, 380 U.S. 89 (1965), and reform of other areas where changes might have been brought about through legislative action prompted by lobbying. It is very difficult to articulate a distinction between these far-reaching changes brought about by litigation (and thus left open to charities under the Code) and those areas denied to charitable groups.

80 In large part the reforms were directed at partisan activity by foundations using taxexempt funds. House Comm. on Ways \& MEANS, TAX Reform Act of 1969, H.R. Rep. No. 91-413, 91st Cong., 1st Sess., pt. 1, at 32 (1969). See also Senate Comm. on Finance, Tax REFoRM Acr of 1969, S. REP. No. 91-552, 91st Cong., 1st Sess. 47 (1969). For the limitations imposed by the Act, see discussion in text and notes at notes 96-98 infra. Several specific cases appear to have been of particular interest, including Ford Foundation funding of the Ocean Hill-Brownsville school decentralization project, Hearings on Tax Reform Before the House Comm. on Ways \& Means [hereinafter cited as Hearings], 91st Cong., 1st Sess., pt. 1 at 44-68 (1969), and several uses of foundation grants as substitutes for campaign contributions, id. at 213-37 (statement and testimony of New York Congressman John J. Rooney).

o1 It is uncertain what income level is necessary before an individual feels he can contribute to charitable organizations. See note 95 infra. It does seem evident that some minimum income level is necessary to assure that the necessities of life are supplied before funds can be spent on other pursuits.

02 See, e.g., statement of Dr. Daniel Tanner, Professor of Education, Rutgers University in Hearings, supra note 90 , at 784, 788:

I am gravely concerned over the trend on the part of certain tax-exempt foundations, 
There is no easy way to resolve doubts about the arguably inequitable effects of enhancing the ability of wealthy individuals to influence public policy. It must be kept in mind, however, that although tax exemptions might enhance the position of those able to afford political expression, at most the inequitable effect is but a reflection of the uneven distribution of income. Avoiding tax exemptions will not cure inequality.

In addition, any fears that such political financing would present only a single point of view are groundless. Although in different eras these fears have alternatively been expressed about domination of tax-exempt foundations by the right ${ }^{93}$ and the left, ${ }^{94}$ there is no convincing evidence that different and diverse points of view are not in fact funded. Donors to charitable organizations come from many different income groups; ${ }^{95}$ thus a tax exemption for political activity would not be a luxury enjoyed only by the very rich.

Moreover, the reforms of 1969 have had the effect of limiting the area of greatest concern-the use of foundation assets to affect public policy, particularly through partisan campaigning. ${ }^{96}$ The Code presently requires that income generated by the capital assets of a foundation be spent during the year it accrues; ;7 continued growth of capital reserves is effectively prohibited. The Code also limits the amount a single donor may deduct in a single tax year, ${ }^{98}$ thereby minimizing

acting individually and collectively, to use their vast and growing resources for the purpose of influencing public policy and legislation. No other organization in our society commands such enormous resources and exercises such great power of political influence without being held responsible to a constituency.

93 Final Report and Testimony submitted to Congress by the Comm. ON Industrial Relations, S. Doc. No. 415, 64th Cong., Ist Sess. (1916). See also F. Lundberg, AMERica's 60 Families (1937); D. Macdonald, The Ford Foundation: The Men and the Mullions (1956); Horowitz \& Kolodney, The Foundations [Charity Begins at Home], RamparTs, April, 1969, at 38.

94 Finax Report of the Select Comm. to Investigate Foundations and Other ORgantzations, H.R. Rep. No. 2514, 82d Cong., 2d Sess. 9 (1953). See also Hearings Before the Spectal Comm. to Investigate TaX-Exempt Foundations and Comparable Organizations,

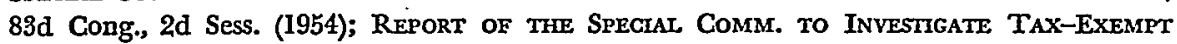
Foundations and Comparable Organizations, H.R. Rep. No. 2681, 83d Cong., 2d Sess. (1954).

95 See U.S. Treas. Dep't, Preliminary Statistics of Income, 1970 Individual Income TAX ReruRns 40 (1972). One-half of the approximately $\$ 13$ billion in charitable deductions in 1970 were taken by taxpayers whose adjusted gross incomes were less than $\$ 15,000$. Furthermore, these lower income donors were shown to have paid almost the same percentage of their adjusted gross income to charity as did their more wealthy counterparts. 98 See generally Note, Regulating the Political Activity of Foundations, 83 HaRv. L. REv. 1843 (1970).

97 INT. REv. CODE OF 1954 \& 4942.

98 Code section $170(\mathrm{~b})$ limits deductions to 20 percent of gross income, with exceptions for certain preferred organizations (churches, regular educational institutions, hospitals, 
the abuses of the privilege of tax deduction by the wealthy, and provides for a tax on foundations for any expenditure spent on noncharitable activities. ${ }^{99}$

Finally, the requirement that funds spent by tax exempt groups be for charitable purposes is itself a guarantee that social benefit should result from the expenditure. ${ }^{100} \mathrm{Much}$ of the concern expressed prior to the passage of the Tax Reform Act of 1969 related specifically to partisan campaign activity ${ }^{101}$ that is not charitable by current standards ${ }^{102}$ and thus would be barred under the proposed revision-discussed later in this comment ${ }^{103}$-which uses as the sole criterion whether the group meets the legal definition of a charity, without regard to the political activities the group may use to accomplish its charitable purposes.

It may also be argued that true equality in public discussion can be achieved only by permitting deductions for contributions to politically active charitable organizations. At present, two groups of individuals, businessmen and contributors to mass political parties, ${ }^{104}$ may deduct at least a portion of their political expenses. These two groups, however, do not exhaust the class of individuals interested in political issues. Indeed, many individuals may find their views represented only by private charitable organizations that, because they do not represent any larger interests, can be more sensitive to minority opinion than can the major political parties. By restraining the political speech of charitable organizations that qualify for 501 (c)(3) status-organizations that might represent numerous different points of view-the present Code provisions do not give these individuals an equal chance to purchase a tax-deductible form of representation.

domestic governments, certain organizations related to these organizations, and public foundations) up to 50 percent of adjusted gross income.

98 Code section 4945 imposes a tax on income spent by foundations for certain nonexempt purposes, without affecting the general tax exempt status of the foundation. Included in the prohibited purposes are any expenditures for purposes other than those specified in section $170(\mathrm{c})(2)$. See note 2 supra. In this way the discrimination inherent in the "substantially involved" criterion discussed earlier, text and note at note 61 supra, is reduced.

100 In addition Code section 507 provides for termination of a private foundation which is found to have made repeated or willful violations of the restrictions of section 501 (c)(3).

101 See note 90 supra.

102 Restatement (SeCond) of Trusts $\& 374$ (1959). Comment $k$ states: "A trust to promote the success of a particular political party is not charitable." See also Boorse Trust, 64 Pa. D. \& C. 447 (Montgomery Gy. 1948); 4. A. ScotT, Trusts $\S 374.6$, at 2914 (3d ed. 1967). 


\section{The Policy of Maximizing Tax Revenues}

Many of the provisions of the Internal Revenue Code are justified as falling within Congress's discretion to adopt rates and methods of taxation that maximize tax revenues. ${ }^{105}$ This policy, however, does not justify the section 501 (c)(3) restriction on political activity. First, the occasional revocations of 501 (c)(3) status due to political activity do not appear to cause any significant increase of tax revenues. The apparent explanation is that potential donors contribute to other exempt organizations that give them the benefit of a deduction from their gross income. ${ }^{100}$

Even a finding that the political activities restriction does increase revenues, however, would not satisfactorily explain why that particular restraint was chosen. A prohibition on speech is hardly the sole means of disqualifying groups and increasing tax revenues. Any variety of other equally artificial prohibitions-for example, eliminating all deductions for contributions to community chests-could have the same effect without raising a first amendment issue. ${ }^{107}$ Thus, if the desire to accumulate increased tax revenues is all that lies behind the prohibition, the preferable approach would be to end the exemption rather than penalize certain groups. The cardinal value of speech is more important than any incidental increase in revenues.

\section{Gonalusions}

The present Code provisions restrict the speech of 501 (c)(3) charitable organizations by conditioning the benefits of that status on the group's abstention from activities protected by the first amendment. Only the clearest and most important government policy would justify

105 The Supreme Court has held that, as an attribute of sovereign powers, governmental units must be permitted to devise fiscal schemes which ensure revenues. Lehnhausen $v$. Lake Shore Auto Parts Co., 410 U.S. 356, 359 (1973); Allied Stores of Ohio, Inc. v. Bowers, 358 U.S. 522, 526-27 (1959).

100 With many thousands of section 501(c)(3) groups from which to choose, a potential donor is likely to be able to find an organization sharing his basic views that also provides him the advantage of a tax deductible contribution.

107 This would seem to be the result mandated by the "least restrictive means" test the Court has occasionally used to determine whether substantial state interests could be adequately served by means that create less restriction on constitutionally protected rights. Justice Marshall summarized this test in Dunn v. Blumstein, 405 U.S. 330, 343 (1972):

[T]he State cannot choose means that unnecessarily burden or restrict constitutionally protected activity. Statutes affecting constitutional rights must be drawn with "precision," NAACP v. Button, 371 U.S. 415, 438 (1963); United States v. Robel, 389 U.S. 258, 265 (1967), and must be "tailored" to serve their legitimate objectives. Shapiro $v$. Thompson, [394 U.S. 618, 681 (1969)]. And iw there are other, reasonable ways to achieve those goals with a lesser burden on constitutionally protected activity, a State may not choose the way of greater interference. If it acts at all, it must choose "Iess drastic means." Shelton v. Tucker, 364 U.S. 479, 488 (1960). 
this procedure, yet it is difficult to construct a compelling justification for this policy that either draws a clear line between political and charitable groups or persuasively shows political advocacy to be socially unproductive.

If the Code simply required that a group be charitable to obtain the benefits of 501 (c)(3) status, 501(c)(3) in combination with the provisions of the common law of charities would accomplish the desired ends of maintaining strict requirements for eligibility and using public subsidies to promote socially beneficial results, without restricting the constitutional rights of charities to pursue political avenues to achieve their goals. This approach might place additional administrative burdens on the Internal Revenue Service and the courts to define "charity" with greater precision. Sharpening a legal concept, however, does not seem too heavy a burden to bear in order to preserve the freedom of expression of charities dependent on the tax exemption for their existenceespecially in light of the extensive common law on charitable trusts that is applicable to this problem. The use of this case law in defining the scope of tax exemptions is consistent with both the purposes underlying charitable exemptions and the constitutionally mandated sensitivity to the free speech rights of charities.

It might be argued that administrative difficulties in defining "charity" are an independent justification for the Code prohibition; it is very difficult, however, to contrast the present Code provisions, which arguably are vague and hard to administer, with the proposed use of a common law definition of charity. Even substantial administrative burdens in defining and applying "charitable" would not necessarily justify the effect of the present provisions on protected speech. It is hard to imagine the added administrative burden being so onerous as to outweigh the charities' strong interests in freedom of speech.

A remaining problem is whether groups involved in partisan political campaigns should be permitted to receive 501(c)(3) status. At present such groups very likely would not be deemed charitable, ${ }^{108}$ at least in part because they would be using their resources to benefit a single individual, the candidate being endorsed and aided. Such individual profit would erode the group's charitable purpose by current standards. It might be argued that, as the definition of charity has evolved over time to include efforts to change existing law, so it should also be expanded to include partisan campaigning. One of the virtues of using the common law to define charities is that the evolution of the legal definition reflects contemporary feelings about what is deserving and 
socially productive activity, and is not bound to rigid guidelines that might have been well suited when they were devised, but arguably are now out of date. Given this background it would not be surprising if the maintenance of an honest and corruption-free method of financing political campaigns eventually achieves the status of a charitable activity, simply because of the social desirability of accomplishing that goal.

John Michael Clear 